\title{
Global democracy: in the beginning
}

\author{
ROBERT E. GOODIN * \\ Philosophy Program, Research School of Social Sciences, Australian National University, Bldg. 09, \\ Canberra ACT 0200, Australia
}

\begin{abstract}
Many who discuss global democracy think in terms of a Reform-Act model of democracy, with the ideal being 'one person one vote for all affected by the decisions' as in, for example, a second popularly apportioned chamber of United Nations. Politically, that is dismissed as wildly unrealistic. Remember, however, the Reform Acts came very late in process of democratization domestically. Among early steps that eventually led to full democratization of that sort domestically were: (a) limiting the arbitrary rule on the part of the sovereign; and (b) making the sovereign accountable to others (initially a limited set of others, which then expanded). Globally, there are moves afoot in both those directions. Crucially, once those pieces are in place, the circle of accountability basically only ever expands and virtually never contracts.
\end{abstract}

Keywords: global democracy; accountability networks; absorbing Markov chains

When people think of democracy nowadays, they tend to think of it primarily in terms of 'one person one vote' - and perhaps (if particularly sophisticated) 'one vote one value'. They tend to think in terms of enfranchising all affected interests. Call that the 'Reform-Act model of democracy', in honor of nineteenth century British legislation expanding the franchise.

That Reform-Act model of democracy is, at root, an electorally oriented, vote-centric vision of what democracy is all about. Academic political theorists point to all sorts of reasons for thinking that merely voting is not all that democracy is about, but for present purposes I eschew all those subtleties. Here, my focus will be on practical politics. In popular political discourse, the Reform-Act model is, for better or worse, the thumbnail version of democracy that is most readily available both for popular consumption and for political implementation.

* E-mail: goodinb@coombs.anu.edu.au 
To appreciate the pervasiveness of that electorally oriented, vote-centric model of democracy just note these examples:

- That is the model of democracy that is most celebrated by liberal internationalists. In awarding the Nobel Peace Prize to Jimmy Carter for 'his decades of untiring efforts to... advance democracy', the Norwegian Nobel Committee (2002) pointed particularly to his service 'as an observer at countless elections all over the world'. ${ }^{1}$ Note similarly that 'encourag[ing] popular participation and support for free and fair elections' comes second on Secretary-General Ban Ki-Moon's (2009: 5) list of priorities for UN democracy assistance.

- That is the model of democracy that neo-conservatives would impose on the rest of the world, by force of arms if necessary. The first thing said under the heading of 'Democratic Governance' in the National Endowment for Democracy's (2007) 'Statement of Principles and Objectives' is: 'Democracy requires a system of representative government in which leaders are chosen in freely contested fair and periodic elections...'.

- That is the model that lies at the heart of the emerging 'right to democratic governance' at international law. There, 'a preoccupation with elections is a striking feature' - to such an extent that 'to raise the question of democracy in international law [just] is largely to raise the question [of] whether international law requires states to hold periodic and genuine elections' (Crawford and Marks, 1998: 80; cf. Franck, 1992).

The italicization in all those cases is mine. The emphases, however, are very much those of the sources cited. Wherever we look, the electorally oriented, vote-centric model really does seem to dominate practical political discourse on democracy.

In discussions of how to democratize international institutions themselves, that same emphasis on fully enfranchised electoral democracy is also much in evidence. That has long been the preferred model of strong internationalists. ${ }^{2}$ When discussing what shape the new United Nations

${ }^{1}$ Carter's activities in support of democracy were only one aspect of his more general human rights promotion cited as grounds for the award.

${ }^{2}$ By which I mean 'people who believe in strong international institutions'. They contrast with 'weak internationalists' who prefer strong states linked through international institutions with only weak authority. They also contrast with 'antistatists' who eschew strong institutions, national or international, in favour of a strong civil society. Much of the current discussion of global democracy is among theorists of vaguely that latter persuasion (Gould, 2004; Kuper, 2004; Dryzek, 2006; Bohman, 1999, 2007), although of course strong internationalists see an important role for strengthening global civil society as well (Held, 1995: Ch. 12; Falk, 2000; cf. Grant and Keohane, 2005: 33-34). By incorporating NGOs and others more closely into the 
should take, British Foreign Secretary Ernest Bevin (1945: 785) urged 'there should be ... study of a house directly elected by the people of the world...'. A half century later, the pre-eminent theorist of cosmopolitan democracy still sees, as 'an unavoidable institutional requirement' of that, 'the establishment of an independent [UN] assembly of democratic peoples', directly elected by them and accountable to them' (Held, 1995: 273). ${ }^{3}$

Any Second Assembly, apportioned according to population as a counterweight to the General Assembly's 'one country one vote', may initially be elected indirectly, consisting of representatives elected by existing national legislatures. Initially, it may be merely a toothless 'talking shop'. Eventually, however, the aspiration is very much for that Second Assembly to become a directly elected People's Assembly with real power.

That proposal was first elaborated in its current form in 1982, at a UN Special Session on Disarmament of all places (Segall, 1982, 1991). Since then, it has attracted the support from a bevy of Non-Governmental Organizations (NGOs), from the United Nations Development Program (1999: 111), and from a range of public intellectuals. ${ }^{4}$ Conspicuous among the latter is Richard Falk, who with Andrew Strauss wrote an influential (2001) Foreign Affairs article in support of the proposal. There they make the case for a 'popularly elected global assembly' - one that 'would represent individuals and society instead of states'. They envisage that as involving:

- the establishment of electoral districts throughout the world...

- global voter rolls...

- a system of campaign finance and other election rules

- [safeguards against] attempts to manipulate or undermine elections... (Falk and Strauss, 2000: 217, 219).

Clearly, what they propose is nothing short of a 'Global Reform Act'.

As an ultimate goal, that is one with which I have considerable sympathy. Philosophically, enfranchising all affected interests surely is the right way of constituting the demos from a democratic point of view (cf. Gould, 2004: Ch. 7; Goodin, 2007). In addition, in today's world, just

work of the UN General Assembly and Economic and Security Council, the Boutros-Ghali Agenda for Democratization (1996: sections 77-103) contributed, fitfully, to that process.

${ }^{3}$ But see Patomäki and Teivainen (2004) for the wide array of other proposals for democratizing global institutions that have been floated.

${ }^{4}$ Preeminent among the NGOs are the INFUSA (International Network for a UN Second Assembly) and its spin-off the CAMDUN (Campaign for a Democratic United Nations). Other public intellectuals include: Franck (1995: 483); Held (1992, 1995: 273-274, 1999: 25); Galtung (2000: 156-158); Patomäki and Teivainen (2004: 30-33 and Ch. 8); and Tännsjö (1992, 2008: 95-106); Archibugi (1993, 2008: 172-177). 
about everyone really is affected (or at least potentially affected) ${ }^{5}$ by just about everyone's decisions and choices, in ways that ought to entitle them to a say in those decisions. Therefore, a Global Reform Act is precisely what democratic principles should prescribe.

In practice, however, such suggestions are hopelessly visionary - or so self-styled realists insist. They see them as, at best, very long-term aspirations that are not remotely realistic in any near future. ${ }^{6}$ As Joseph Nye (2001: 4) says, in starkly realist mode: 'Alfred, Lord Tennyson's "Parliament of Man" made for great Victorian poetry, but it does not stand up to contemporary political analysis'.?

The pronouncements of self-styled realists ought always be taken with a grain of salt. They often tend to be too realistic. Realists often fold their highest moral aspirations far too quickly in the face of obstacles that might well have been eminently surmountable, had only they tried (Goodin, 1992). Speaking as president of the UN General Assembly, Edvard Hambro wisely remarked, 'Politics should be the art to make possible tomorrow what seems impossible today' (quoted in Kuper, 2004: 45). Long before, Max Weber had said the same at the end of his famous lecture on 'Politics as a Vocation'.8

Generally skeptical, though I thus ordinarily am of realists' excessive realism, on the present point I fear they are almost certainly correct. It is simply too early to be thinking of democratizing the global order along Reform-Act lines. ${ }^{9}$ But remember - and this is the key point of this article - the Reform Acts came very late in the process of democratizing the domestic polity. Those were the very last steps, not the first steps, in that long process. ${ }^{10}$

${ }^{5}$ Which elsewhere I argue is the correct standard (Goodin, 2007).

${ }^{6}$ Other realists query whether it is desirable at all, sharing Kant's (1795) concern over what might happen if we instituted a global government that then turned dictatorial.

${ }^{7}$ Nye is referring to a line from Tennyson's 'Locksley Hall'. See further: Dahl (1999); Keohane and Nye (2002). Even sensible critical theorists agree (Habermas, 2001: 107-109; Scheuerman, 2006: 95-96).

${ }^{8}$ Describing politics as 'a slow, powerful drilling through hard boards, with a mixture of passion and a sense of proportion', Weber (1919/2004: 93) elaborates: 'It is absolutely true, and our entire historical experience confirms it, that what is possible could never have been achieved unless people had tried again and again to achieve the impossible in this world'.

${ }^{9}$ Although the Commission on Global Governance's (Carlsson and Ramphal, 2005: Ch. 7) proposal for a 'Forum of Civil Society' representing NGOs accredited to the General Assembly might be getting some traction, with backing from UN Secretaries General and various panels of eminent persons (Boutros-Ghali, 1996; Annan, 2002: paras 134-141; Cardoso, 2004; Panyarachun, 2004: para. 243).

${ }^{10}$ Some places - conspicuously including the American South - it took another century to realize the Reform Act ideal fully, of course. 
When it comes to the global polity, we are still very much in the early days - both of developing a global polity, and still more of democratizing it. What we should be looking for in that context are 'first steps', not final steps. It should be no cause for despair that we are not (yet) in a position to undertake the sorts of reforms that would mark the culmination of democratization on a global scale. ${ }^{11}$

When looking for a template for democratizing our emerging global institutions, we should not be looking at how democracy has developed 'at the end of the day' (Fukayama, 2006). Instead, we should be looking at how democracy developed 'in the beginning'. Modeling like-on-like (Hui, 2001), we should be looking at domestic developments, not in the nineteenth century, but instead five or six centuries earlier.

\section{Democratization before the vote, domestically}

Pulling us out of that nineteenth-century Reform-Act mindset, and casting our minds back to those earlier periods, what were the key developments that contributed most crucially to democratization in the very beginning?

Two steps stand out ${ }^{12}$ :

- The first was curbing the arbitrary exercise of power. ${ }^{13}$

- The second was rendering power-holders accountable to someone or another.

Of course, the way in which we eventually came to curb the arbitrary exercise of power was to make power holders accountable. Therefore,

11 There is of course a chicken-and-egg issue of democratic legitimacy, here. The only way to make international institutions democratic is to cede some power to them and then hold them increasingly to account for how they exercise it. But in the very first instance, before they yet very democratically accountable, that amounts (at least for countries that are themselves genuinely democratic in their internal governance) to transferring power from a more democratic regime to a less democratic one (Rabkin, 2005). I would myself regard that as a 'democracy-democracy tradeoff', i.e. less democracy now for more later. Even in the short term, working through international (or even just multilateral) regimes can help in important ways to make domestic regimes that are all inevitably imperfectly democratic more democratic (Keohane et al., 2009).

12 The Inter-American Commission of Human Rights identified precisely these two requirements in its 1990 Report on Haiti: 'The concept of representative democracy is rooted in the principle that political sovereignty is vested in the people which, in the exercise of that sovereignty, elects its representatives to exercise political power... The effective enjoyment of these rights and freedoms requires a legal and institutional order in which the law takes precedence over the will of the rulers and some institutions have control over others in order to preserve the integrity of the popular will (the constitutional state)' (OAS, 1990: paras 15, 16). Held, (1999: 105-106) refers to the combination as constituting 'democratic public law'. Grant and Keohane (2005: 42) concur, in passing.

${ }^{13}$ Wrongly neglected in much recent political theory, as both Shapiro (1996: 582, 1999: Ch. 1) and Young (2000: 174) rightly argue. 
nowadays those two steps have come to be conflated. But note well: that was a later conflation of two steps that, at the beginning, were clearly distinct. In the very first instance, what was essential to repudiate the principle that the sovereign's word was law, and to establish instead that the sovereign ruled under law. That, roughly, was the accomplishment of the Magna Carta of 1215 , as it was interpreted and reinterpreted over the years. ${ }^{14}$

Once it was established as a matter of principle that the sovereign could not exercise power in any arbitrary way he (or occasionally she) pleased, discussion could then turn to questions of how best to embed that principle in practice. Making the sovereign accountable to someone or another requiring the sovereign to give reasons for acting as he or she had done was seen to be one way of doing that. Establishing that was, roughly, the accomplishment of the Bill of Rights of 1689, as that was interpreted and reinterpreted over the years. ${ }^{15}$

Historically, those were two distinct steps separated in Britain by over four centuries. In between times, arbitrary exercises of sovereign power were prohibited, but it was beyond the power of any human agent to sanction them. ${ }^{16}$ Not only were non-arbitrariness and accountability separated historically. They are logically distinct, as well. Requiring that people have reasons is clearly distinct from requiring them to give reasons. As a purely contingent matter, of course, requiring people to give reasons (through some accountability mechanism) might be the most effective practical way of ensuring that they actually have reasons, and are not just acting on some arbitrary whim. But that is a practical convenience, not a logical necessity.

Furthermore, there is a natural sequence to those two requirements. ${ }^{17}$ Certain political rights presuppose - practically, if not strictly logically certain civil rights. A right to vote pragmatically presupposes, for example,

${ }^{14}$ Starting with Bracton and his famous slogan 'law makes the king', rather than the other way around (quoted in Corwin 1928-9/1955: 27). See further: Pocock (1957: esp. Ch. 2); Jennings (1959: Ch. 1); Holt (1965); Berman (1983: 292-294).

15 Whitehead (2002: 92, n.3) sees clause 61 of the Magna Carta as a key step toward 'executive accountability'. In some sense it is, but only a small one, since it applies only to cases in which the king is 'out of the kingdom' (Holt, 1965: 335; see more generally Lock, 1989).

16 Bracton, again, was clear on this point: 'The king is under no man (non-sub homine), even if he is under God and the law.... Obviously, the king can do wrong, even if the penalty can... be exacted by none but God the avenger' (glossed by Mcllwain, 1947: 72, 82). See similarly Hobbes (1651: Ch. 21).

17 Those familiar with T.H. Marshall's (1949/1963; cf. Somers 1994) famous analysis of the evolution of social citizenship will recognize the story I am telling, here. For Marshall, first come civil rights (my 'rule of law'); then come political rights (to hold officials accountable at elections); and then come economic and social rights (a step is beyond the scope of my present discussion). Stalin's so-called 'democracy', like Schmidt's, may well proceed along a different developmental path. But that seems a natural sequence at least in liberal democracies, for reasons given in the text. 
a right of habeas corpus. No election is free and fair if rulers can lock up opposition supporters to prevent them from voting. Giving people a right to demand that they be charged before a court of law protects against (among many other things) arbitrary arrests being used in this way to alter election outcomes. ${ }^{18}$

More fundamentally, unless the sovereign is bound by the rule of law, there is no pragmatic point in anyone else's having the right to vote to determine the content of that law. ${ }^{19}$ Requiring an election without requiring that rulers be bound by its outcome would be a nonsense, or anyway a sham. In this most fundamental respect, the rule of law truly is a prerequisite, and not a merely accidental precursor, to democratic political rights of more recognizably Reform-Act sorts.

Whether there is some similarly inexorable logic dictating where it all must necessarily end up - whether it is somehow inevitable that curbs on the arbitrary exercise of power and institutions holding the powerful to account must necessarily end in democracy of the fullest Reform-Act sort - is a question to which I shall return below.

\section{First steps toward global democracy}

With these domestic analogies in place, let us return to the topic of global democracy. Similar things seem to be happening in today's international order as happened centuries ago in the domestic sphere to curtail the arbitrary exercise of power and to make it accountable. Of course, there is no reason to suppose that these developments need necessarily follow exactly the same path everywhere, internationally as well as domestically. Interestingly enough, however, international developments do seem to be following uncannily similar paths to those domestic ones long ago.

\section{Curbing arbitrary exercises of power}

As UN Secretary General, Kofi Annan (2006) was fond of quoting a remark of President Truman's (1945) to the closing session of the San Francisco conference that founded the United Nations. There Truman said, 'We all have to recognize - no matter how great our strength - that we must deny ourselves the license to do always as we please' (quoted in Annan, 2006).

${ }^{18}$ I am grateful to Larry May for this example.

19 Even democratization theorists who would 'start with rights', and who are anxious to have a robust human rights regime in place alongside majoritarian democracy, must recognize the preeminence of the 'rule of law'. Only if that is in place will there be a venue in which rights claims can be heard. 
Doubtless the UN Secretary General was so fond of those words for a reason. US presidents - and power-holders more generally - clearly need to be reminded of that home truth at least once every generation. However often forgotten, the principle was nonetheless clearly established back then, and it is increasingly being enshrined in international law and international political practice today.

At the level of international practice, we can point to a plethora of treaty regimes with increasingly strong enforcement mechanisms. Emblematic of this is the shift from the voluntary dispute settlement mechanism found in the General Agreement on Trade and Tariffs to the mandatory one found in World Trade Organization. ${ }^{20}$ One could equally well point to the International Criminal Court as acknowledgment (at least among the treaty's signatories) of norms of international law that are binding even on notional sovereigns in the state system.

Treaty regimes, however, are just the formalized tip of the international legal iceberg. If our concern is with the emergence of norms curbing arbitrary exercises of power by state actors, an even better place to look might be to what international lawyers call jus cogens. Treaties are things that sovereign states negotiate among themselves, and they bind only those who sign them. Jus cogens, in contrast, does not require the consent of any particular state before it is legally binding on that state. Shifting from treaties to jus cogens as a basis of international law marks a 'shift from consent to consensus as the basic source of international law' (Bull, 2002: 150). ${ }^{21}$

Thus, in addition to international conventions and international custom, sources of international law under jus cogens also include 'the general principles of law recognized by civilized nations' (even if this particular state does not recognize that particular principle) and 'judicial decisions and the teaching of the most highly qualified publicists of the various nations' (even if states generally fail to recognize them). ${ }^{22}$ Prohibitions on the use of force, on genocide, and on gross violations of human rights have all become part of binding jus cogens in just that way. They apply even to states that have not ratified treaties on those topics.

${ }^{20}$ Patomäki and Teivainen (2004: 71). It is no mystery why the shift has occurred: it served the interests even of the very strongest, in ways set out by Krasner (2000: 234).

21 Although Bull himself doubts that sufficient international solidarity exists for that to be presently practicable. I take May's (2004) point that grounding jus cogens in international custom, as is typically done in this literature, encounters the problem of the 'persistent objector': why should a state be bound by the customary practices of or consensus among other states, when it has always objected to that custom or consensus? It may well be that jus cogens must ultimately be grounded in universal moral norms, of the sort I shall discuss next.

22 ICJ (2007), Art. 38.1. As Brownlie (1990: 3) says, this 'is generally recognized as a complete statement of the sources of international law'. 
More generally, there is movement toward a 'rule of law' within the international sphere. ${ }^{23}$ That does not necessarily presuppose any centralized lawgiver. Instead, the rule of law emerges out of customary international law in the same dispersed way the common law emerged domestically. It is inevitably 'soft law', at least in its early stages, based on vague norms rather than precise enforceable edicts with authorized interpreters (Abbott and Snidal, 2000; Abbott et al., 2000). In the very first instance it is far from being universally acknowledged. But the more states that are party to those arrangements, the more advantageous it often is for others to join in those arrangements and the more disadvantageous it is for others to remain outside them. ${ }^{24}$ Therefore, the cooperative network naturally expands, eventually encompassing virtually all countries in ways I shall further elaborate below.

Of course, when it comes to imposing rules of international law on powerful states that insistently do not want any part of them, questions of enforceability inevitably arise. Paraphrasing Andrew Jackson's riposte to the US Supreme Court, they can always just adopt the stance: 'The World Court has made its decision; now let's see the World Court enforce it' (Warren, 1926: vol. 1, 759). The US famously took just the same stance toward the International Court of Justice's (1986) decision in Nicaragua vs. United States. Therefore, if a global superpower is hell-bent on throwing its weight around in completely arbitrary and illegitimate ways, it can still do so even in the face of all this emerging jus cogens and international rule of law.

But before despairing too deeply about that, remember that we were in broadly the same position domestically for a couple of centuries after the Magna Carta. The arbitrary exercise of power had been repudiated. It had been accepted that the sovereign's word was not itself law; it had been accepted that, instead, the sovereign ruled under law. It simply took a little more time before any practical way was found for mortal men to (as was said back then) 'put a bridle on him' (McIlwain, 1947: 69). Still, the point having been established, the path was set.

So, too at the international level, 'almost all nations observe almost all principles of international law and almost all their obligations almost all

${ }^{23}$ Archibugi and Young (2002); Goodin (2005); Archibugi (2008: 144-147). The Report of the Special Representative of the UN Secretary-General on Business and Human Rights provides a most interesting discussion of how this expanding rule of law might even be stretched to make business corporations responsible for respecting international human rights (Ruggie, 2007: 14-18).

${ }^{24}$ Reus-Smit (2003). That is not always the case (e.g. assuming increasing marginal harm to the environment from each extra increment of pollution, the more other states curb their pollution the less important it is for your state to do so). But it is often enough to make soft law largely stick. 
of the time', even if there is no one who can strictly make them do so. There is every reason to hope that may continue to be true even as the scope of international law expands from the strictly contractual to the more broadly consensual (Henkin, 1968: 42; Koh, 1997). It is to those reasons that I turn, next.

\section{Mutual accountability via networked governance}

In today's international society, there is also a flowering of accountability mechanisms analogous to those in the earlier stages of domestic democratization (Grant and Keohane, 2005: 36). Virtually none of them is itself directly democratic, in the first instance. But they are nonetheless valuable as accountability mechanisms, for that fact. In addition, as I shall argue below, there is a natural dynamic by which, once such mechanisms are put in place, the circle of those to whom the powerful are accountable almost inevitably expands over time.

The early thought, domestically, was that the sovereign must consult 'his curia..., and the earls and barons who are his associates there'. In addition, as one early slogan put it, 'one who has an associate has a master ${ }^{25}$ - or anyway he has an equal to whom he is accountable.

The basic idea there was one of mutual accountability among associates joined in cooperative networks to pursue shared (or anyway parallel) purposes. That same sort of mutual accountability within networks increasingly characterizes relations among states, International Organizations, Non-Governmental Organizations and Inter-Governmental Organizations in today's increasingly globalized world. ${ }^{26}$

Policy networks, epistemic communities and professional associations all 'create and maintain transnational norms to which NGOs, InterGovernmental Organizations (IGOs) and government officials can be judged accountable' (Keohane and Nye, 2002: 239-240). These networks involve everything from states and International Organizations through non-governmental actors (ranging from Amnesty International, Transparency International, and Greenpeace International) all the way to private actors (such as Moody's and Standard and Poor's). Serving in effect as 'private overseers of national governments' (Scott, 2002: 60), these networks

25 Attributed to Bracton, although it was almost certainly a later annotation (McIlwain, 1947: 69).

${ }^{26}$ For purposes of this brief discussion, I focus on one particular type of accountability what Grant and Keohane (2005: 36) call 'peer accountability' (and what others call 'horizontal accountability' (Bovens, 2007) or 'horizontal responsiveness' (Kuper, 2004: 103)). There are several other types of accountability at work globally today, as Grant and Keohane (2005) ably show - just as there were in earlier eras domestically. I focus on this particular one purely for ease of exposition, here. 
have notched up some very real accomplishments as itemized in a recent UN Report: 'Global policy networks have significantly influenced policy, shaped public opinion and helped to resolve disputes on such issues as debt, landmines, small arms, conflict diamonds, big dams, and crimes against humanity...' (Cardoso, 2004: 33, para. 51).

In the limiting case, a pure network has no hierarchy. No one stands in authority over anyone else. Therefore, strictly speaking, no one would have to answer to anyone. Such networks are purely voluntary. They operate purely on the basis of trust and the reputation for trustworthiness (Kreps, 1990; see further Sørensen and Torfing, 2007). Of course realworld networks are not pure in this respect - but insofar as they have more structure than that, cooperation within them becomes only easier to orchestrate.

In the limiting case, a pure network would also lack any formal mechanisms for sanctioning members. A pure network would rely instead on more informal processes of 'naming and shaming' and 'shunning', insofar as enforcement is required at all. ${ }^{27}$ Nevertheless, insofar as participants value the esteem of others in the network and want to continue doing business with them, those seemingly weak sanctions might actually suffice to facilitate productive collaboration. All of that is of course all the more true in the more mixed cases of networks found in the real political world that have far greater power to sanction members through consumer boycotts, international sanctions, withholding resources, and such like (Braithwaite and Drahos, 2000; Castells, 2000).

Having more structure and sanctions, those real-world accountability networks are even easier to mobilize. But even in the limiting case, pure networks could make a very real difference by linking people and organizations that share common concerns and values. Mutuality would be their hallmark. Each participant would internalize the perspective of the others. Naturally, differences of opinion would still exist within any given network. But confident that they all share some important purposes, participants in such networks would be more likely to respect one another's opinions, to explore the bases of their differences and to make good-faith efforts to find common ground (March and Olsen, 1995: Ch. 2).

To a hard-bitten realist, all that may seem pretty airy-fairy. Such skepticism notwithstanding, that is precisely how networks do often work in the real world. One good example is Concert of Vienna multilateral conference diplomacy and the conventions that grew up around it

${ }^{27}$ Sometimes a cooperative scheme is self-enforcing. With 'network externalities' of the sort discussed below, for example, each wants more to be part of the scheme, the more others, there are in the scheme. 
(Mitzen, 2005). Another example is found in the informal interactions among delegates that go on in the corners of formal meetings of UN General Assembly committees and that do so much to shape outcomes there (Alger, 1966).

Perhaps the best description from the inside of how all this works is Gunnar Myrdal's account of his time as Executive Secretary of the United Nation's Economic Commission for Europe. That organization eventually gave rise to increasingly strong organizations - the European Economic Community, and thence the European Union itself. But in its early days, when Myrdal was its Executive Secretary, it was only a very loose intergovernmental organization, almost like the pure networks I have just been describing. Here is how Myrdal (1955: 8, 20) describes that organization as functioning:

[Once the] organization ... settles down to a tradition of work, ... the same state officials come together at regular intervals.... Certain substitutes for real political sanctions can then gradually be built up. They are all informal and frail. They assume a commonly shared appreciation of the general usefulness of earlier results reached, the similarly shared pride of, and solidarity towards, the 'club' of participants at the meetings.... Not upholding an agreement is something like a breach of etiquette in a club.

That is accountability of a sort. It worked in the medieval king's curia, after a fashion. It worked in the Concert of Vienna and still does in UN committees, after much the same fashion. It is working after much the same fashion internationally today, through networks within and between states, International Organizations (IOs), NGOs, and IGOs. ${ }^{28}$

The accountability is imperfect (Esmark, 2007). IOs, NGOs, and IGOs depend upon the support of states in myriad ways, making them less independent loci of accountability than ideally we would wish. But remember, so too were medieval barons dependent upon the king for all sorts of things, at the same time as he depended on them for others.

Worse, from the perspective of democratizing the global community, the groups to whom today's international actors are accountable are themselves internally not particularly democratic (as yet). But remember, the

\footnotetext{
${ }^{28}$ It ought also be acknowledged that networks can pursue evil purposes as well as noble ones. Organized crime and terrorist cells work through networks of mutual accountability. In addition, climate-change deniers find plenty of governments, NGOs and IGOs to bundle into an effective network of mutual accountability for their own nefarious purposes. But the same was historically true in the domestic case: the king's curia often constituted a conspiracy against the interests of the larger public lacking a seat in that chamber.
} 
unreformed seventeenth-century Parliament to which the Bill of Rights made William and Mary accountable was not all that democratic, either.

The first step is to get the accountability regime in place. The next steps are to strengthen and to democratize it. There are steps afoot to do just that, internationally, insofar as both the United Nations and European Union now decline to enter in formal consultative relationships with groups that do not themselves have democratic internal governance structures. $^{29}$

\section{Dynamics of democratization, domestically}

Thus it seems that democratization of the global community is up to roughly where it was domestically in Britain around the seventeenth century. So far, so reassuring. But what grounds are there for thinking the rest of the process will play itself out internationally in the same democratic way as it did domestically? Why think that we might end up with anything remotely resembling a Global Reform Act with one-person-one-vote worldwide?

I cannot pretend to predict particular paths toward global democratization. Even domestically, we have only sketchy outlines of possible 'transition paths' toward democratization (Linz and Stepan, 1996: Ch. 4). Likewise, highly stylized accounts are the best that can be expected internationally. Therefore, I shall once again be operating a couple degrees of abstraction above any particular historical experiences. In sketching paths toward global democratization, my aim will merely be to identify some generic features of the democratization process, leaving open how exactly they might be instantiated on any particular occasion.

Still less can I pretend to predict the pace of global democratization. Perhaps the fact that democratic ideas are already well established in one jurisdiction or at some other level of governance might enable democratization to proceed more quickly elsewhere or later. Nationally, late

29 The UN Economic and Social Council (1996: section 12) establishes 'consultative relations' with non-governmental organizations only on this condition: 'The organization shall have a representative structure and possess appropriate mechanisms of accountability to its members, who shall exercise effective control over its policies and actions through the exercise of voting rights or other appropriate democratic and transparent decision-making processes'. See similarly the White Paper on European Governance of the European Union's Commission (2001: 4, 16-17). cf. the UN Panel of Eminent Persons recommending 'removing those restrictions' so as to 'open the United Nations to vital contributions from other constituencies and increase their sense of ownership of global goals' (Cardoso, 2004: 32, para. 41). Grant and Keohane $(2005: 38,42)$ similarly argue that democratic accountability is not the only form that matters, not only as applied to NGOs, but also more generally, saying 'strict analogies from domestic democrtic politics should be regarded with skepticism, and we should resist the temptation to narrow the issue of accountability to that of democratic control'. 
democratizers often accomplish in half a dozen years what took early democratizers like Britain as many centuries. Perhaps that same might prove true internationally. Or perhaps not, ${ }^{30}$ I simply offer no speculations on the likely pace of global democratization.

As regard the direction of future developments, however, I shall be more committal. Here I shall sketch a process that, if I am correct, inexorably pushes the political system in a more democratically inclusive direction.

The basic model I shall be advancing is one of a 'slippery slope in one direction'. There are two salient features of the process, as I shall characterize it:

(1) From time to time there emerges some crisis, to which expanding the range of people to whom power-holders are accountable is sometimes a solution. ${ }^{31}$

(2) Accountability mostly only expands, it almost never contracts.

Taken together, those two factors guarantee the eventual predominance of democracy worldwide, both domestically (as I shall argue in this section) and internationally as well (as I shall subsequently go on to argue).

\section{An example: extending the franchise}

Think of the history of expansions of the franchise. At first, the monarch was answerable to only a handful of barons. Over time, more and more people were drawn into that circle, and eventually universal adult suffrage was achieved. It was not achieved because of any great good will on the part of those already within the charmed circle - Mill was quite wrong to expect that. ${ }^{32}$ There were just crises, from time to time, to which

${ }^{30}$ Countries that democratize late often enjoy the benefit of external support (financial, election monitoring, international organizations that can serve as commitment devices) that is available because others have democratized before them. There may be no equivalent source of external support for democratizing the international system as a whole (although democratizing one part of it might provide similar external support for subsequent efforts at democratizing other parts of it).

31 Acemoglu and Robinson (2000) offer empirical evidence, Myerson (2008) an elegant formal model.

32 'John Stuart Mill looked forward in October 1831 to a time when 'the whole of the existing institutions of society are leveled with the ground. After the first reformed Parliament 'the ground will be cleared,' he wrote. .... The Poor Man's Guardian announced on 26 May: 'We cannot think so ill of human nature as to think that those who will... have gained their own freedom will not aid us to gain ours'. But as it turned out, 'Middle-class people, once given the vote, wanted to conserve institutions that they had formerly been inclined to attack. Most of the new voters wanted, not to challenge the aristocracy, but to win recognition from it: once they had their rightful position they did not favour further adventures' (Brock, 1973: 315, 319). 
extending the vote to additional groups was a solution. ${ }^{33}$ In addition here is the crucial point - once expanded, the franchise virtually never contracts. ${ }^{34}$

Of course we can all think of exceptions. ${ }^{35}$ In the United States, the most glaring is the way blacks in the South won voting rights during Reconstruction, only to lose them again once the federal forces departed. That is very much the exception that proves the rule, however. An eminent historian of that episode is emphatic on that point:
No major social group in Western history, other than African Americans, ever entered the electorate of an established democracy and then was extruded by nominally democratic means..., forcing that group to start all over again. In Europe, Latin America and elsewhere, liberal democracies never sponsored disenfranchisement. Once previously excluded social groups came into any established system, they stayed in (see further: Therborn, 1977; Freeman and Snidal, 1982; Mackie and Rose, 1991; Valelly, 2004: 1-2).

That may be overstating the point a little - but only a little. Thus, for example, the French revolution enfranchised many people who were subsequently disenfranchised (although given the character of Napoleon's regime, that was not by even 'nominally democratic means'). The Reich Citizenship Law of 15 September 1935 disenfranchised Jews and anyone else who was not 'of German or related blood' (but again, while it was duly elected, one could certainly question whether the regime enacting that law was genuinely democratic). There are other smaller-scale instances. For example, convicted felons in the United States are often disenfranchised, sometimes for life, with racially differentiated consequences (Western, 2006). Or for another example, Commonwealth citizens resident in the UK enjoyed

${ }^{33}$ Wars and the need for support during them is a notable one: the nineteenth-century Swedish slogan was 'one man, one vote, one gun' (Przeworski, 2009: 3); and during World War I the German Emperor had to make his peace with trade unions and social democrats, on the grounds that 'in a castle under siege you have to see to it that everything inside it is harmonious' (Claus Offe, personal correspondence). Similarly, economic elites eventually come to see the benefits of giving the working classes the vote, 'institutionalizing class struggle' within the political realm and thus removing it from the economic (Lipset, 1963).

${ }^{34}$ The usefulness of the franchise might contract. Tilly (2007: 64) recalls how, 'In France, Louis Napoleon cut back the [power of the] National Assembly with his 1851 coup but did not quite dare to reinstate property qualifications for male suffrage'; and he points to similar patterns in nineteenth-century Germany and Greece. A more contemporary example might be when democratically accountable state power ekes out into the democratically unaccountable market, under regimes of neoliberal economic reform.

${ }^{35} \mathrm{My}$ focus here is narrowly on political rights, and more narrowly still (in this paragraph anyway) on voting rights. Thinking of social rights more generally, there certainly has been a certain amount of ebb and flow over time: for example, just think of the status of women's rights in Iran, Afghanistan, and Pakistan. 
voting rights there until they were withdrawn by the Immigration Act of 1972. There are all those exceptions, to be sure. Still, those are exceptions to what proves to be an astonishingly strong general rule.

The most systematic empirical investigation on this subject has been undertaken by Adam Przeworski (2009). He provides an exhaustive survey of changes to election laws in 187 countries, from the time they first established national electoral institutions to the present.

Przeworski's findings are striking. He finds that movement is in the 'increasingly democratic' direction - from more restrictive to less restrictive franchise provisions - in nearly ninety percent of cases. ${ }^{36}$ On this, the best evidence we have, it thus seems that the franchise takes nine steps forward, for every one it takes backward.

\section{Democracy as an absorbing Markov chain}

Here is an analogy that might help in explicating the basic structure of the model I have in mind. Imagine a deep hole, such that once you fall into it you can never get out. People are not particularly drawn into the hole. They just pass by it from time to time, and occasionally they fall in. But since everyone passes the hole from time to time, and on some occasion or another eventually falls in - and since no one can get out once they have fallen in - everyone eventually ends up in the hole. ${ }^{37}$

Two things make that model work. The first is the risk of falling in; the second is the impossibility of getting out. Both are obviously necessary for the working of the model. The way I have set up this model, however, it is the second rather than the first that does most of the work.

I emphasize that point because models of democratization usually take the opposite tack. Their emphasis is more ordinarily upon factors that push institutions in democratic directions: having a strong middle class or a strong union movement or whatever (Lipset, 1960; Jackman, 1972; Geddes, 1999). Or their emphasis falls teleologically on pull factors: in public-choice mode, on the way in which majority rule can (given sufficient uncertainty) maximize expected benefits for all concerned (Rae, 1969); or on the way in which strong institutions (democratic or otherwise) can be sources of stability (Huntington, 1968).

I do not want to deny any of that. I want merely to ask, 'Just how strong do those push-pull forces need to be, in order for democratization

${ }^{36}$ Przeworski (2009: 299, Table 1). Of the 389 instances of change to franchise provisions reported, 349 are in that direction and only 40 in the other.

37 This is a special case of Alastair MacIntyre's (1972) 'general theory of holes'. Claus Offe wryly replies, 'Of course elites will try to build a fence around it...'. But try as they might, they will not always succeed; and this model requires only that there be occasional gaps in the fence. 
eventually to be fully accomplished?' On the ordinary account, they need to be pretty strong and pretty persistent. On the model I am here suggesting, they can be pretty weak and pretty intermittent. All my model requires is that power-holders at least occasionally get themselves into jams, and that expanding the circle of accountability is one (perhaps among many) ways of getting themselves out of those jams. ${ }^{38}$ Those occasional crises are what drive us in a more democratic direction, to be sure. They are important parts of the model, for that reason. But basically they can be treated just as random shocks, in my model.

My model can allow the pressures toward democratization to be just that weak, because on my model the 'stickiness' of democracy is strong. If democratization is basically a one-way ratcheting-up process, and the circle of accountability only expands and almost never contracts, then institutions will over time become increasingly democratic even with only very weak pressures in that direction.

What my hole analogy describes is, of course, just a folksy example of an 'absorbing Markov chain'. ${ }^{39}$ If there is some positive probability of transition from any other state into some 'absorbing' state, and zero probability of transition out of it, then everything will end up in that absorbing state eventually. How quickly depends just on how frequently transitions occur, and on the probability that any given transition will lead us into the absorbing state.

Completely absorbing states are of course rare. More commonly, there are merely highly differential probabilities of transitions into and out of the various states. The expanding-franchise story is one of an 'almostabsorbing' Markov chain, with movement into the expanded-franchise state being roughly nine times as likely as movement out of it. The point nonetheless remains: even with a merely almost-absorbing Markov chain, just about everyone will eventually fall into in the almost-absorbing state, and just about everyone will then stay there.

To the categories of completely absorbing and almost-absorbing states should be added the further category of 'increasingly-absorbing' states. Consider for example network externalities. There, the more people who are in a certain state, the more you want to be in that state yourself. The more people who are connected to the telephone line or to the internet, for example, the more beneficial it is for you to be connected yourself (Katz and Shapiro, 1985; Grewal, 2008: ff. 25). Or for another different

\footnotetext{
${ }^{38}$ War, xenophobia and repression are other ways, from time to time. I do not deny that they will sometimes be used, with brutal effect. I merely claim that they are not enduring and cumulative, in the way that democratic reforms tend to be.

39 Stinchcombe (1968: 105; 1974).
} 
kind of example, consider the case of increasing returns to scale. The more you are already doing of something, the higher the payoff to you per unit cost of doing yet more of it (Pierson, 2000). In both cases, the allure of some state of the world is an increasing function of your proximity to it. ${ }^{40}$

\section{Mechanisms}

Why should any of that be so, when it comes to transitions toward democracy? Here I point to three mechanisms - one cultural, one psychological, and one sociological. Together, they work hand-in-glove to produce that result in the domestic case. I shall focus in this section on the domestic case, reserving discussion of the international case for later.

The first mechanism that makes moves toward democratic inclusiveness so 'sticky' in the domestic case is the cultural shift that comes from acknowledging each other as equals. That having been once done, it is virtually impossible to go back. Sans-culottes can be forced back into their place, of course, but force is then required to do what had previously been accomplished by acculturation alone (Sonenscher, 2008). After a culture of egalitarianism had once been created, recreating the old culture of a statusdifferentiated society of 'my station and its duties' is well nigh impossible (Bradley, 1876; Shklar, 1991). That, as much as any ratchet effect of wartime taxing and spending (cf. Peacock and Wiseman, 1961), is what explains postwar expansions of the welfare state (Dryzek and Goodin, 1986).

The second source of 'stickiness' of moves toward democratic inclusiveness in the domestic case is a psychological mechanism, 'loss aversion'. People are invariably much more sensitive to the prospect of losing something they already have than they are to the prospect of gaining the same thing if they do not yet have it. There is evidence aplenty of this tendency from social psychology and experimental economics experiments (Kahneman and Tversky, 1979; Tversky and Kahneman, 1991). There is evidence aplenty in the frequency of 'hold harmless' clauses and the need to 'grandfather in' existing uses and existing beneficiaries when changing public policy on everything from regulatory policy through land use controls to social security entitlements.

The third source of that 'stickiness' of moves toward democratic inclusiveness is sociological in character. Once people have been mobilized, it is hard to demobilize them (Tilly, 1997; McAdam et al., 2001). Standing down armies after a war is perhaps the most literal case in point: decommissioning weapons, hard though it may be, is the easy part; harder

\footnotetext{
${ }^{40}$ Note that increasingly-absorbing states are different from the other two kinds, in that their 'increasing-absorbingness' rather 'draws you into the fold' instead of merely keeping you in it once there.
} 
to overcome is the fact that, among the former brothers in arms, the 'strength of weak ties' remains (Granovetter, 1973). It is always easier to get people back together again, after they have once been together, than it was to get them together in the first place.

Those three mechanisms, separately and especially when acting in unison, are what make it so difficult to disenfranchise people after they have once won the franchise. Beyond the franchise, those factors make it similarly difficult to curtail accountability of any sort after it once has been expanded. Once power-holders have been made accountable to someone, electorally or otherwise, the same cultural, psychological, and sociological forces conspire to constrain any rollback of that accountability.

\section{Ruptures}

So far, I have been talking about dynamics within democratic systems of governance. The three mechanisms just discussed make it hard for a system that remains even 'nominally democratic' to reduce the range of people to whom power holders are democratically accountable. ${ }^{41}$

But there can of course be a breakdown of the democratic system altogether (Linz and Stepan, 1978). Through revolution or counterrevolution, invasion or coup, democratic institutions can be suspended and replaced with others (or in the case of 'failed states', with none). Clearly in those cases, the cumulative progress toward expanding democratic accountability unravels. $^{42}$

I do not suppose there is any predicting what the future might hold for catastrophically failed states, or even for ones suffering very long bouts of foreign occupation or domination. ${ }^{43}$ But consider democracies that have less dramatic interruptions to their democratic development, such as military coups.

Clearly, with a coup, democracy takes a step backwards. Elections are suspended and democratic rights are abrogated. Notice, however, this crucial fact. When democracy is eventually restored after the coup, it tends to pick up where it left off. The country does not 'Return to Go' and start all over again on the long and torturous route that had led it to the stage of democracy it enjoyed before the coup. Instead, the old

${ }^{41}$ In this focus I have been following Valelly (2004: 1-2).

42 Valelly (2004: 2) concedes that 'disenfranchisements certainly took place... when the type of regime changed', as happened several times in century France $(1793,1848,1852$, until universal male suffrage was adopted for good in 1884).

43 After all, it took millennia to restore democracy in Athens. See more generally Bates (2008). 
constitution is typically restored pretty much holus bolus. ${ }^{44}$ The same old rules apply once again. Everyone who used to have voting rights gets them back again. Democracy picks up where it left off. ${ }^{45}$ In addition, the same might be true even with more dramatic interruptions to democratic development.

Students of comparative political history will doubtless think of a few counterexamples to that generalization. ${ }^{46}$ As with expansions of the franchise, so too with restorations of democratic rule: the most we can confidently say is that the circle of accountability 'almost never contracts'. Looks like a pretty reliable 'stylized fact', at least as regard domestic politics. There are counterexamples, to be sure, but the rarity of counterexamples constitutes confirmation of the rule.

\section{Extending the model, internationally}

How applicable is all of this at the international level? Well, casual empiricism offers plenty of confirmatory examples. Notice that the Organisation for Economic Co-operation and Development has only ever expanded, it has never contracted. The G-7 has become the G-8, which has become the G-20 (more of which below). The range of NGOs with official consultative status at the Economic and Social Council of the UN has mostly only expanded and virtually never contracted. The United Nations picked up pretty much where the League of Nations left off. And so on. All that makes the proposition that 'accountability basically

${ }^{44}$ Sometimes the new constitution bans some parties. In some cases, like one-party democracies of Africa after decolonization, that looks like a clear violation of democratic rights of association. In other cases, it is not so clear that the ban is undemocratic; consider for example the case of Article 21 of the Basic Law of the Federal Republic of Germany empowers the Constitutional Court to ban political parties for being anti-democratic in a way that was not possible under the Weimar constitution (Allemann, 1956).

45 That is clearly the case where democracy is restored under the old constitution that the coup suspended. But it is also most typically the case in 'successor states' that are not official continuers of some previous one. This is certainly true at the level of basic policy structures, anyway: the same basic social insurance structure, for example, persisted in Germany from Bismarck through the Nazi period to the Federal Republic of Germany and the German Democratic Republic; Heidenheimer et al. (1975: 231) rightly call this continuity 'remarkable... in light of the vast upheavals in twentieth-century Germany'.

46 The generalization is only meant to apply to instances of indigenous, not externally imposed, democratization. When a conqueror imposes democratic forms that have no domestic roots in the country upon which they are imposed, it is less uncommon for those forms to be repudiated when the conqueror departs. The post-Reconstruction history of the American South - blacks gaining the vote under Reconstruction but losing it again as soon as federal troops departed - is a case in point. Another is the racially restricted franchise introduced as the Union of South Africa gained independence from Britain. 
expands rather than contracts' look pretty plausible as a stylized fact about politics in general, international as well as about domestic.

Still, generations of students of international relations have rightly been taught to be on guard against any too-easy appeal to 'the domestic analogy' (Suganami, 1989). It would be clearly mistaken to take it purely as axiomatic that politics between states is necessarily perfectly isomorphic with politics within states, any just as it would be clearly mistaken to take it purely as axiomatic that the way in which states behave in a situation of anarchy is necessarily perfectly isomorphic with the way individuals do.

Neither, however, is it necessarily the case they are completely different. Sometimes they are, sometimes not. We simply need to check whether the particular domestic analogy being drawn is or is not appropriate. The best way to do that, I suggest, is through a close inspection of the details of the model and the mechanisms at work within it (Tilly, 2001; Tilly and Goodin, 2006; Elster, 2007). Those are precisely the 'points of analogy' in the analogies being drawn between domestic politics and international politics. If similar mechanisms can be shown to be at work in both cases, then on that point the analogy will have been vindicated.

The model of domestic democratization offered above had two key components:

(1) From time to time there emerges some crisis, to which expanding the range of people to whom power-holders are accountable is sometimes a solution.

(2) Accountability, mostly only expands, it almost never contracts.

The first component is a very weak one ('from time to time...'; 'sometimes...'). Accordingly, all I need to do to vindicate the analogy on that point is to provide an existence proof - to show that some such thing also happens internationally, at least occasionally. I do that below via the case of the G-20. The second component is what does most of the work in my model. To vindicate the analogy on that point, I then go on to show that the three mechanisms identified above for the domestic case are also heavily at work internationally as well.

\section{Crises expand accountability: the G-20}

For a compelling example of how crises can arise in global affairs, to which expanding the circle of accountability can be a solution, consider how the G-20 supplanted the G-8 in response to the 2008 meltdown of the global economy. Although far from unique, that is a paradigm case in all sorts of respects: the crisis was truly a major one; the bodies in question had formal memberships, one larger the other smaller; and since those bodies work by unanimous consent, the newly included members 
gained real power when authority was transferred from the smaller to the larger group. Best of all, those facts can all be read right off the face of official communiqués issued at the end of each meeting. ${ }^{47}$

The history in a nutshell is this. With the demise of the Bretton Woods exchange rate regime and in the wake of the 1973 oil crisis, there was a felt need for a small, focused forum to enable the world's leading industrialized democracies to coordinate management of the global economy. The G-6 (US, UK, France, FRG, Italy, and Japan) was formed for this purpose at a 1975 heads of government summit convened by President Valery Giscard d'Estaing in Ramoouillet. ${ }^{48}$ That morphed into the G-7 (with the addition of Canada a year later) and thence the G-8 (with the addition of Russia a decade after that). Under that aegis, summits of heads of government were held annually and meetings of finance ministers quarterly.

Other entities were represented at G-8 meetings in more limited ways. Among them were the European Union, the World Bank and the International Monetary Fund. Some emerging economies - the Outreach Five (Brazil, China, India, Mexico, and South Africa) - were also invited to attend for some but not all items of business. Basically, however, the G-8 served as a 'rich countries' club' that informally steered the world economy.

As a sop to the emerging economies, a larger G-20 was formally established in $1999 .{ }^{49}$ Its initial task was described in milquetoast terms 'to broaden the discussions on key economic and financial policy issues among systemically significant economies' (G-20, 1999: para. 2). The final communiqués of those meetings (initially just of finance ministers and central bank governors) confirm that just such broad 'deep-background' discussions of fairly inconclusive or inconsequential sorts were indeed the order of those early days.

With the global financial meltdown in 2008, however, the smaller G-8 clearly could no longer manage the global economy on its own. There was an urgent need to involve representatives of a wider set of the world's economies. In Washington in December 2008, national leaders of G-20 members met for the first time, saying that 'the global crisis requires global solutions.... The G-20, with its broad representation of major systemically important economies, has a critical role to play in ensuring global financial and economic stability...'. (G-20, 2008a: paras 2, 4; see further G-20, 2008b).

\footnotetext{
47 Collected at http://www.g20.org/pub_communiques.aspx

48 Building on earlier meetings of the 'Library Group' of the US, UK, France and Germany convened in the library of the White House by US Treasury Secretary George Schultz in 1973, and subsequent iterations (Baker, 2008).

${ }^{49}$ Its membership includied the G-8 plus Argentina, Australia, Brazil, China, the European Union, India, Indonesia, Mexico, Saudi Arabia, South Africa, South Korea, and Turkey.
} 
Expanding on that proposition in the final communique from their April 2009 London summit, G-20 national leaders proclaimed:

We start from the belief that prosperity is indivisible; that growth, to be sustained, has to be shared; and that our global plan for recovery must have at its heart the needs and jobs of hard-working families, not just in developed countries but in emerging markets and the poorest countries of the world too; and must reflect the interests, not just of today's population, but of future generations too. We believe that the only sure foundation for sustainable globalization and rising prosperity for all is an open world economy based on market principles, effective regulation, and strong global institutions.

Emerging markets and developing countries, which have been the engine of recent world growth, are also now facing challenges, which are adding to the current downturn in the global economy. It is imperative for global confidence and economic recovery that capital continues to flow to them (G-20, 2009a: paras 3, 17).

In their November 2009 meeting in Pittsburgh, the leaders of the G-20 countries went further still. There, they formally proclaimed that the G-20 would henceforth take the place of the G-8 as the entity charged with principal responsibility for managing the world economy. The closing paragraph of their communique bluntly spelt the death knell for the old G-8, stating: 'Today, we designated the G-20 as the premier forum for our international economic cooperation' (G-20, 2009b: para. 50)

A clearer case could not be found of the emergence of a global crisis, to which widening the circle of global accountability was offered as a response. It happens, at least occasionally, at the international level just as at the domestic. How often it happens I leave as an open question, just as I did in my discussion of the domestic case above.$^{50}$ For the purposes of my model of democratization, it is sufficient that it happens 'from time to time'.

\section{Mechanisms: sources of stickiness, internationally}

The real workhorse in my model of domestic democratization is the proposition that 'accountability mostly only expands, it almost never contracts'. Three mechanisms were identified to account for that in the domestic case. The task of this section is to assess the extent to which the

${ }^{50}$ I similarly leave as an open question whether there are limits to how far it will extend. Once the G-20 has grown to the G-37 or G-92, there might be some feeling that it is too unwieldy a decision-making body, and some smaller 'Executive Committee' created to exercise the real power within the organization. 
same sorts of mechanisms might also be at work internationally, leading expansions of accountability there to be similarly hard to reverse.

The first thing to note is that, even at the level of domestic politics, one of the mechanisms I identify - the psychological phenomenon of 'loss aversion' - is essentially an extrapolation from an individual-level phenomenon. The thought, domestically, is that groups are more likely organize to resist losing what they already have because individuals resist losing what they already have.

Of course we know from Olson's (1965) logic of collective action that it is a fallacy to suppose groups will necessarily organize to pursue interests that members of that putative group share. In more instrumental settings, individuals might rationally be inclined to be free riders, benefiting from others' paying the costs of the group activity that would benefit them whether or not they played a part in that activity themselves. But that is a rational, instrumental calculation. Psychological mechanisms evoke a more visceral and less considered response, operating (to some extent or another) 'behind the backs' of intentional agents. Insofar as 'loss aversion' evokes that sort of a response, the prospects for collective action are less undermined by Olson's (1965) 'logic'. Shared psychological responses may then translate fairly directly into concerted group action.

Furthermore, there is every reason to suppose that the same psychological dynamics would lead people who stand to lose to organize collectively to lobby against such developments, be they foreign or domestic. The costs of transnational organization might be higher (although they are getting lower all the time, with new communication technology). But there is every reason to think that the psychological impetus - loss aversion - would lead people to make common cause with others who stand to lose in the same way from the same policies worldwide.

Sometimes everyone in the same country would stand to suffer identical losses from some development, which they therefore all oppose. More often, everyone in some subset of people in a country (or straddling several countries) stands to lose, and they resist on those grounds. As a sort of shorthand, we might explain those reactions by saying that country or group as a whole was manifesting 'loss aversion', although strictly speaking of course loss aversion is a psychological phenomenon and it is only individuals, not groups or countries, that are possessed of psyches. The point remains: the 'loss aversion' mechanism works the same way in both internationally and domestically to make people, individually and in groups, resist efforts to remove democratic accountability once they have been granted it.

The other two mechanisms I discussed in relation to the stickiness of domestic democratization are more genuinely group-level phenomena. 
The story I told about the sociological effects of mobilization pointed to the 'strength of weak ties'. One reason that it is easier to renew collaborations has purely to do with information: you already know who to talk to about what, on the basis of previous experience; you have some sense of what they are interested in, of what position they are likely to take, of what resources they have access to, and so on. Overlaid on that is a 'reciprocity' dynamic: people with whom you have interacted in the past, and with whom you expect to interact again in the future, are people whose past actions you will reciprocate, even if only as an investment in your own future payoffs (Bowles and Gintis, 2002). A reasonably strong 'mobilization effect' is thus easily generated.

Networks thus mobilized have been shown to be powerful forces in international relations just as in neighborhood organizing. The stories of 'activists beyond borders', for both human rights (Keck and Sikkink, 1998; Risse et al., 1999) and environmental protection (Zürn, 1998), bear rich testimony to that fact. Already knowing how important such networks can be in global politics, we need only add the further fact that networks are hard to destroy completely once they have been mobilized, in order to appreciate another important source of 'stickiness' in global accountability mechanisms. As with armies so too with global networks, once mobilized they are hard to demobilize completely.

The final mechanism making expansions of domestic democratic inclusiveness hard to undo had to do with a more diffuse notion of a 'cultural shift'. Once we have come to regard one another as equals, it is hard to go back to thinking of one another in status-differentiated terms. Of course, insofar as that is a fact about human psychology, it will hold true across national borders as well as within them. But insofar as the culture in question is a national political culture, then the effect of a culture shift might well stop at the national borders. Citizens of postrevolutionary France could think of one another as equals, without for a moment of counting Britons or Spaniards in that category as well.

For there to be some analogous mechanism at work globally, therefore, we would have to posit a political culture that transcends national borders and to point to hard-to-reverse shifts occurring in that culture. The best evidence I can offer of that comes from recent work on the role of 'norms' within the international community (Finnemore and Sikkink, 1998). There are many penetrating accounts of the importance of such norms, of the processes by which they get established, and of the ways in which they change. For a quick and easy demonstration, let me here focus on one norm in particular, the 'decolonization' norm. That is a good place to fix our focus for multiple reasons. For one thing, independent selfgovernment, is an important democratic accomplishment in its own right. 
For another, the number of countries under foreign rule, just like the number of people denied the vote, is readily countable; and we can therefore easily assess just how decolonization has spread and just how (in)frequently it is reversed. Finally, while decolonization is of course only one example of a norm of trans-national political culture, there is no reason to suppose that it is at all atypical of the way other democratic norms would work in international society.

Graphs plotting the rate of decolonization over time show modest flurries in the late eighteenth and early nineteenth centuries, as colonies in the Americas won their freedom. After a long hiatus, the rate picks up dramatically after the First World War and more dramatically again after the Second (Strang, 1991: 436; see also Goertz and Diehl, 1992: 653). As with extensions of the franchise domestically, so too with decolonization internationally: there was occasionally a little backsliding. ${ }^{51}$ But basically, the movement was almost all in the one direction. Furthermore, close scrutiny of debates surrounding various cases of decolonization suggest that a cultural shift was indeed one key driver of that. Norms of decolonization took hold precisely when, and because, people - both in the metropole and especially in the colonies themselves - came to be imbued with notions of democratic equality.

Thus, it seems that all three of the same mechanisms might be at work internationally as have historically been at work domestically to ensure that moves toward ever-broader circles of accountability will be hard to reverse.

\section{First find a state}

There is one last potential point of disanalogy between democratizing domestic institutions and international ones. That might be encapsulated in the phrase, 'first find a state'. 52

The thought is that, in order to democratize a state, you first must have a state to democratize. ${ }^{53}$ Before you can democratize central institutions of authority, you have to have some central institutions of authority. In the

${ }^{51}$ For example, in its 1785 Constitution, post-Revolutionary France 'elevated its overseas colonies to full equality with the metropolis', only for them to be 'returned to dependent status under Napoleon in 1803' (Strang, 1991: 434).

52 All the democracies discussed in the large literature on democratic transition and consolidation are 'successor states' (Linz and Stepan, 1996); global democracy would have to be 'self-founding', which is something much harder. I am grateful to Claus Offe for this formulation.

${ }^{53}$ Linz and Stepan (1996: 17), for example, say that 'without a state, no modern democracy is possible'. 
domestic case, we had them. In the international case, we do not - or anyway not yet. ${ }^{54}$ If we define democratization in terms of 'a transfer of sovereignty from the prince to the people', then we need a prince possessed of sovereignty before he can transfer it to the people (cf. Goodhart, 2007: 574). Or so the thought might go. ${ }^{55}$

Of course, as historians of state formation will immediately interject at this point, the central institutions of authority in the state were themselves awfully thin in the early period that is most analogous to today's international order. Maybe the king could claim a territory, but what the putative sovereign could do by way of ruling over it was in practice pretty circumscribed (to claim authority is one thing, to exercise it is quite another...).

It is perfectly true that no one even claims sovereignty over the whole globe, as yet. But that is not to deny that there are any institutions, international in scope, which could be subject to a push for democratization. Obviously, there are many. These institutions exercise global authority in piecemeal fashion, functionally, defined. But whoever said - whoever would think - that only central authorities with a perfectly general remit admit of being democratized? Notwithstanding its functionally delimited scope of authority, a school board can be made more democratically accountable (by, e.g. making its members be popularly elected). Therefore too the World Trade Organization: its authority is functionally delimited, but that constitutes no conceptual barrier to its exercising that authority in a more or less democratic fashion. ${ }^{56}$ In addition, so on down the list of functionally delimited power-holders in the global arena.

Would democratizing the partial and piecemeal institutions of global governance amount to a contribution toward global democracy? Surely it would. The only reason for doubting that is that we sometimes fail to

54 Although Wendt (2003) gives reasons - substantially orthogonal to the path dynamics discussed in this article - for believing a 'world state is inevitable', in the long run.

${ }^{55}$ Nagel (2005: 146) puts this point particularly forcefully: 'Unjust and illegitimate regimes are the necessary precursors of ... progress toward legitimacy and democracy, because they create the centralized power that can then be contested, and perhaps turned in other directions without being destroyed. For this reason, I believe the most likely path toward some version of global justice is through the creation of patently unjust and illegitimate global institutions of power that are tolerable to the interests of the most powerful current nationstates. Only in that way will institutions come into being that are worth taking over in the service of more democratic purposes, and only in that way will there be something concrete for the demand for legitimacy to go to work on'.

${ }^{56}$ Minimalist proposals for democratizing WTO include measures for greater transparency (restricting access to fewer documents, opening WTO meetings to the public, etc.) and to broaden the range of agenda-setters (by including new states, perhaps on a rotating basis, in the group of Quad or in the work done in the Green Room). For such proposals, see: Krajewski (2001); Patomäki and Teivainen (2004: 83-84). 
notice that two dimensions are in play here. First, political institutions can be strong or weak; second, they can be democratic or not. If we have some strong central authority, and we democratize it, we end up with a strong democratic institution. If we have only weak central authorities with limited remits, and democratize them, we end up with weak democratic institutions with limited powers. But the institutions are no less democratic for their being weak in that way (Dahl and Tufte, 1973).

That leads to one final speculation. Perhaps democratizing institutions might pave the way for strengthening those institutions. ${ }^{57}$ That was certainly the case with kings and parliaments: they became stronger as, and because, they became more democratic. Maybe it will prove to be so with global institutions as well. Perhaps what is fundamentally required to strengthen those institutions, too, is that they be democratized. ${ }^{58}$

\section{Acknowledgements}

This article has been presented as the Edmund Burke Lecture at Trinity College, Dublin, at the Universities of Bergen, Harvard, Oxford, Queensland, and Turku, at the City University of New York, at the Czech Academy of the Sciences in Prague and at the 2008 Annual Meetings of the American Political Science Association. The author grateful for valuable feedback to all those audiences, most particularly from: Daniele

${ }^{57}$ Having a robust 'global civil society' (the sorts of accountability networks discussed above) is a necessary but - pace some deliberative democrats (Gould, 2004; Kuper, 2004; Dryzek, 2006; Bohman, 2007) - not sufficient condition of robust global democracy. Ultimately, that will require more institutional structure.

${ }^{58}$ How to build global institutions, and to do so in a democratic fashion, is a large topic on which much has been written. Roughly speaking, the options seem to be these. First, you can rely on 'democratic politics from the outside' to hold international institutions that are not themselves internally democratic externally accountable to civil society (i.e. the NGO strategy of Transparency International). Second, you can run Marshall (1949) in reverse: start with global welfarestate redistribution, which gives everyone reason to try to acquire civil and political rights to help shape its future of a regime in which they now have a stake. Third, you could start by democratizing supranational regional organizations and expand from there, either through a 'demonstration' effect or through expanding the catchment of the regional organizations (a variation on the 'external supports' discussed in footnote 30 above). Fourth, you can try to expand the scope of nonpolitical, technical international policymaking, what Habermas calls 'global domestic policy making': policing (oceans, the drug market, protection of species, etc.) can be seen as a non-political matter to be left to technical experts; being initially perceived as non-political allows transference of these responsibilities to an expert community worldwide; but as these tasks subsequently become clearly politicized, that leads to demands for grater global democratic control of them. (I am grateful to Claus Offe for discussions mapping out this rough catalogue). Obviously, all the classical work on state-building (Rose, 1976; Tilly, 1990; Rokkan, 1999) is relevant here. But it is obviously, a much larger issue than can be properly canvassed here. 
Archibugi, Magdalena Balcerak, Derek Bok, Michael Biggs, Dave Chalmers, Jurgen De Wispelaere, Keith Dowding, John Dryzek, Katrin Flikschuh, Carol Gould, David Grewal, Gudmund Hernes, Andy Hurrell, Stein Kuhnle, Leon Leontyev, Terry MacDonald, Jenny Mansbridge, Raffaele Marchetti, Larry May, Cillian McBride, Sue Mendus, David Miller, Hannu Nurmi, Martha Nussbaum, Claus Offe, Frances Fox Piven, Eric Posner, Mathias Risse, David Rodin, Duncan Snidal, Torbjörn Tännsjö, Dennis Thompson, Mike Titelbaum, Laura Valentini, Lea Ypi, Michael Zürn, and the editors of and referees for this journal.

\section{References}

Abbott, K., R.O. Keohane, A. Moravcsik, A.-M. Slaughter and D. Snidal (2000), 'The concept of legalization', International Organization 54: 457-488.

Abbott, K.W. and D. Snidal (2000), 'Hard and soft law in international governance', International Organization 54: 421-456.

Acemoglu, D. and J.A. Robinson (2000), 'Why did the west extend the franchise? Democracy, inequality and growth in historical perspective', Quarterly Journal of Economics 115: 1167-1190.

Alger, C.F. (1966), 'Interaction in a committee of the United Nations general assembly', Midwest Journal of Political Science 10(4): 411-447.

Allemann, F.R. (1956), Bonn ist Nicht Weimar, Köln: Kiepenheuer \& Witsch.

Annan, K.A. (2002), 'Strengthening of the United Nations: an agenda for further change', Report of the Secretary-General, United Nations General Assembly A/57/387. Retrieved 11 December 2006 from http://www.un-ngls.org/Strenghening_United_Nations_an_ agenda_for_further_change.pdf

_ (2006), 'Speech at the Truman Library'. Retrieved 11 December 2006 from http:// www.un.org/News/ossg/sg/stories/statments_full.asp?statID $=40$

Archibugi, D. (1993), 'The reform of the UN and cosmopolitan democracy: a critical review', Journal of Peace Research 30(3): 301-315.

- (2008), The Global Commonwealth of Citizens, Princeton, NJ: Princeton University Press.

Archibugi, D. and I. Young (2002), 'Envisioning a global rule of law', Dissent 49: 27-32.

Baker, A. (2008), 'The group of seven', New Political Economy 13(1): 103-115.

Ban, K.-M. (2009), 'Guidance note of the secretary-general on Democracy'. Retrieved 11 December 2006 from http://www.un.org/democracyfund/Docs/UNSG\%20Guidance\% 20Note\%20on\%20Democracy.pdf

Bates, R.H. (2008), 'State failure', Annual Review of Political Science 11: 1-12.

Berman, H.J. (1983), Law and Revolution: The Formation of the Western Legal Tradition, Cambridge, MA: Harvard University Press.

Bevin, E. (1945), 'Speech in the house of commons, 23 November 1945', Hansard's Parliamentary Debates 416: 759-846.

Bohman, J. (1999), 'International regimes and democratic governance: political equality and influence in global institutions', International Affairs 75: 499-513.

- (2007), Democracy Across Borders: From Demos to Democracy, Cambridge, MA: MIT Press.

Boutros-Ghali, B. (1996), An Agenda for Democratization, New York: United Nations. 
Bovens, M. (2007), 'New forms of accountability and EU-governance', Comparative European Politics 5(1): 104-120.

Bowles, S. and H. Gintis (2002), 'Homo reciprocans', Nature 15(68): 125-128.

Bradley, F.H. (1876), 'My station and its duties', in F.H. Bradley and R.G. Ross (eds), Ethical Studies, Indianapolis, IN: Bobbs-Merrill, 1951, pp. 98-147.

Braithwaite, J. and P. Drahos (2000), Global Business Regulation, Cambridge: Cambridge University Press.

Brock, M. (1973), The Great Reform Act, London: Hutchinson University Library.

Brownlie, I. (1990), The Principles of Public International Law, 4th edn., Oxford: Clarendon Press.

Bull, H. (2002), The Anarchical Society, 3rd edn., London: Palgrave.

Cardoso, F.H., chair (2004), 'We the peoples: civil society, the United Nations and global governance', Report of the Panel of Eminent Persons on United Nations-Civil Society Relations, United Nations General Assembly A/58/817. Retrieved 11 December 2006 from http://www.un-ngls.org/orf/Final\%20report\%20-\%20HLP.doc

Carlsson, I. and S. Ramphal, co-chairs (2005), 'Our global neighborhood', Report of the Commission on Global Governance, Oxford: Oxford University Press. Retrieved 11 December 2006 from http://www.sovereignty.net/p/gov/ogn-front.html

Castells, M. (2000), 'Materials for an exploratory theory of the network society', British Journal of Sociology 51(1): 5-24.

Corwin, E.S. (1928-1929), 'The "higher law" background of American constitutional law', Harvard Law Review 42: 149-185, 365-409, reprinted as The "Higher Law" Background of American Constitutional Law, Ithaca, NY: Cornell University Press, 1957.

Crawford, J. and S. Marks (1998), 'The global democracy deficit: an essay in international law and its limits', in D. Archibugi, D. Hels and M. Köhler (eds), Re-imagining Political Community: Studies in Cosmopolitan Democracy, Stanford, CA: Stanford University Press, pp. 72-90.

Dahl, R.A. (1999), 'Can international organizations be democratic: a sceptic's view', in I. Shapiro and C. Hacker-Cordon (eds), Democracy's Edges, Cambridge: Cambridge University Press.

Dahl, R.A. and E.R. Tufte (1973), Size and Democracy, Stanford, CA: Stanford University Press. Dryzek, J.S. (2006), Deliberative Global Politics, Cambridge: Polity Press.

Dryzek, J.S. and R.E. Goodin (1986), 'Risk-sharing and social justice: the motivational foundations of the post-war welfare state', British Journal of Political Science 16(1): 1-34.

Elster, J. (2007), Explaining Social Behaviour: More Nuts and Bolts for the Social Sciences, Cambridge: Cambridge University Press.

Esmark, A. (2007), 'Democratic accountability and network governance - problems and potentials', in E. Sørensen and J. Torfing (eds), Theories of Democratic Network Governance, London: Palgrave Macmillan, pp. 274-296.

European Union, Commission (2001), 'European Governance: a white paper', COM(2001)428 final. Retrieved 11 December 2006 from http://europa.eu.int/comm/governance/white_ paper/index_en.htm

Falk, R. (2000), 'Global civil society and the democratic prospect', in B. Holden (ed.), Global Democracy: Key Debates, London: Routledge, pp. 143-162.

Falk, R. and A. Strauss (2000), 'On the creation of a global peoples assembly: legitimacy and the power of popular sovereignty', Stanford Journal of Intenational Law 36: 191-220. (2001), 'Toward global parliament', Foreign Affairs 80: 212-220.

Finnemore, M. and K. Sikkink (1998), 'International norm dynamics and political change', International Organization 52(4): 887-917. 
Franck, T.M. (1992), 'The emerging right to democratic governance', American Journal of International Law 86: 46-91.

- (1995), Fairness in International Law and Institutions, Oxford: Oxford University Press.

Freeman, J.R. and D. Snidal (1982), 'Diffusion, development and democratization: enfranchisement in Western Europe', Canadian Journal of Political Science 15(2): 299-329.

Fukayama, F. (2006), The End of History and the Last Man, 2nd edn, New York: Simon and Schuster.

G-20 (1999), 'Communiqué: Meeting of G-20 Finance Ministers and Central Bank Governors, Berlin'. Retrieved 15-16 December 1999 from http://www.g20.org/Documents/ 1999_germany.pdf

G-20 (2008a), 'Communiqué: meeting of ministers and governors, Sao Paulo, Brazil'. Retrieved 8-9 November 2008 from http://www.g20.org/Documents/2008_communique_ saopaulo_brazil.pdf

G-20 (2008b), 'Declaration: summit on financial markets and the world economy', final communiqué, Washington, DC. Retrieved 15 November 2008 from http:// www.g20.org/Documents/g20_summit_declaration.pdf

G-20 (2009a), 'Leaders' statement: the global plan for recovery and reform', final communiqué, London. Retrieved 2 April 2009 from http://www.g20.org/Documents/final-communique. pdf

G-20 (2009b), 'Leaders' statement: the Pittsburgh Summit, September 24-25, 2009', final communiqué. Retrieved 25 September 2009 from http://www.g20.org/Documents/ pittsburgh_summit_leaders_statement_250909.pdf

Galtung, J. (2000), 'Alternative models for global democracy', in B. Holden (ed.), Global Democracy: Key Debates, London: Routledge, pp. 143-161.

Geddes, B. (1999), 'What do we know about democratization after twenty years?', Annual Review of Political Science 2: 115-144.

Goertz, G. and P.F. Diehl (1992), 'Toward a theory of international norms: some conceptual and measurement issues', Journal of Conflict Resolution 36(4): 634-664.

Goodhart, M. (2007), 'Europe's democratic deficits through the looking glass: the European Union as a challenge for democracy', Perspectives on Politics 5: 567-584.

Goodin, R.E. (1992), 'The political realism of free movement', in B. Barry and R.E. Goodin (eds), Free Movement, University Park: Pennsylvania State University Press, pp. 248-264.

- (2005), 'Toward an international rule of law: distinguishing international law-breakers from would-be law-makers', Journal of Ethics 9: 225-246.

- (2007), 'Enfranchising all affected interests, and its alternatives', Philosophy \& Public Affairs 35: 40-68.

Gould, C.C. (2004), Globalizing Democracy and Human Rights, Cambridge: Cambridge University Press.

Granovetter, M. (1973), 'The strength of weak ties', American Journal of Sociology 78: $1360-1380$.

Grant, R.W. and R.O. Keohane (2005), 'Accountability and abuses of power in world politics', American Political Science Review 99(1): 29-43.

Grewal, D.S. (2008), Network Power: The Social Dynamics of Globalization, New Haven, CT: Yale University Press.

Habermas, J. (2001), The Postnational Constellation, trans. M. Pensky, Cambridge, MA: MIT Press.

Heidenheimer, A.J., H. Heclo and C.T. Adams (1975), Comparative Public Policy, 3rd edn, London: Macmillan. 
Held, D. (1992), 'Democracy: from citystates to a cosmopolitan order?', Political Studies 60(5): 10-39.

- (1995), Democracy and the Global Order, Cambridge: Polity.

(1999), 'The transformation of political community: rethinking democracy in the context of globalization', in I. Shapiro and C. Hacker-Cordón (eds), Democracy's Edges, Cambridge: Cambridge University Press, pp. 84-111.

Henkin, L. (1968), How Nations Behave: Law and Foreign Policy, New York: Palgrave.

Hobbes, T. (1651), Leviathan, London: Andrew Crooke.

Holt, J.C. (1965), Magna Carta, Cambridge: Cambridge University Press.

Hui, V.T.-b. (2001), 'The emergence and demise of nascent constitutional rights: comparing ancient China and early modern Europe', Journal of Political Philosophy 9: 372-402.

Huntington, S.P. (1968), Political Order in Changing Societies, New Haven, CT: Yale University Press.

International Court of Justice (1986), 'Nicaragua v. United States'. Retrieved 11 December 2006 from http://www.icj-cij.org/icjwww/Icases/iNus/inus_ijudgment/inus_ijudgment_ 19860627.pdf

International Court of Justice (2007), 'Statute of the International Court of Justice'. Retrieved 11 December 2006 from http://www.icj-cij.org/documents/index.php?p1=4\&p2= $2 \& \mathrm{p} 3=0$

Jackman, R. (1972), Politics and Social Equality, New York: Wiley.

Jennings, I. (1959), The Law and the Constitution, 5th edn., London: University of London Press.

Kahneman, D. and A. Tversky (1979), 'Prospect theory: an analysis of decision under risk', Econometrica 47: 263-291.

Kant, I. (1795), 'Perpetual peace', in H. Reiss (ed.), Kant's Political Writings, Cambridge: Cambridge University Press, 1970, pp. 93-130.

Katz, M.L. and C.C. Shapiro (1985), 'Network externalities: competition and comparability', American Economic Review 75: 424-440.

Keck, M. and K. Sikkink (1998), Activists Beyond Borders: Advocacy Networks in International Politics, Ithaca, NY: Cornell University Press.

Keohane, R.O., S. Macedo and A. Moravcsik (2009), 'Democracy-enhancing multilateralism', International Organization 63(1): 1-31.

Keohane, R.O. and J.S. Nye Jr. (2002), 'The club model of multilateral cooperation and problems of democratic legitimacy', in R.O. Keohane (ed.), Power and Governance in a Partially Globalized World, London: Routledge, pp. 219-244.

Koh, H.H. (1997), 'Why do nations obey international law?', Yale Law Journal 106: 2599-2659.

Krajewski, M. (2001), 'Democratic legitimacy and constitutional perspectives of WTO law', Journal of World Trade 33(1): 167-186.

Krasner, S.D. (2000), 'Power and constraint', Chicago Journal of International Law 1: 231-236.

Kreps, D.M. (1990), 'Corporate culture and economic theory', in J. Alt and K. Shepsle (eds), Perspectives on Positive Political Economy, Cambridge: Cambridge University Press, pp. $90-143$.

Kuper, A. (2004), Democracy Beyond Borders: Justice and Representation in Global Institutions, Oxford: Oxford University Press.

Linz, J.J. and A. Stepan (eds) (1978), The Breakdown of Democratic Regimes: Crisis, Breakdown and Reequilibration, Baltimore, MD: Johns Hopkins University Press.

— (1996), Problems of Democratic Transition and Consolidation, Baltimore, MD: Johns Hopkins University Press. 
Lipset, S.M. (1960), Political Man, New York: Doubleday.

— (1963), The First New Nation, New York: Basic Books.

Lock, G. (1989), 'The 1689 Bill of Rights', Political Studies 27(4): 540-561.

MacIntyre, A. (1972), 'Is a science of comparative politics possible?', in P. Laslett, W.G. Runciman and Q. Skinner (eds), Philosophy, Politics \& Society, 4th series, Oxford: Blackwell, pp. 8-26.

Mackie, T.T. and R. Rose (1991), The International Almanac of Electoral History, 3rd edn., Washington, DC: Congressional Quarterly.

March, J.G. and J.P. Olsen (1995), Democratic Governance, New York: Free Press.

Marshall, T.H. (1949), 'Citizenship and social class', reprinted in Marshall, Class, Citizenship and Social Development, Chicago: University of Chicago Press, 1963, pp. $70-134$.

May, L. (2004), Crimes Against Humanity, Cambridge: Cambridge University Press.

McAdam, D., S. Tarrow and C. Tilly (2001), Dynamics of Contention, Cambridge: Cambridge University Press.

McIlwain, C.H. (1947), Constitutionalism: Ancient and Modern, Ithaca, NY: Cornell University Press.

Mitzen, J. (2005), 'Reading Habermas in anarchy: multilateral diplomacy and global public spheres', American Political Science Review 99(3): 401-417.

Myerson, R.B. (2008), 'The autocrat's credibility problem and foundations of the constitutional state', American Political Science Review 102(1): 125-140.

Myrdal, G. (1955), Realities and Illusions in Regard to Inter-governmental Organizations, L. T. Hobhouse Memorial Trust Lecture No. 24, delivered at Bedford College, London, 25 February 1954, London: Oxford University Press.

Nagel, T. (2005), 'The problem of global justice', Philosophy \& Public Affairs 33: 114-147.

National Endowment for Democracy (NED) (2007), 'Statement of principles and objectives: strengthening democracy abroad; the role of the National Endowment for Democracy'. Retrieved 11 December 2006 from http://www.ned.org/about/principlesObjectives.html

Norwegian Nobel Committee (2002), 'The Nobel Peace Prize 2002'. Retrieved 11 December 2006 from http://nobelprize.org/nobel_prizes/peace/laureates/2002/press.html

Nye, J.S.Jr. (2001), 'Globalization's democratic deficit: how to make international institutions more accountable', Foreign Affairs 80(4): 2-6.

Olson, M.Jr. (1965), The Logic of Collective Action, Cambridge, MA: Harvard University Press.

Organization of American States (OAS), Inter-American Commission on Human Rights (1990), 'Report on the Situation of Human Rights in Haiti'. OEA/Ser.L/V/II.77 rev.1, doc. 18. Retrieved 8 May 1990 from http://cidh.oas.org/countryrep/Haiti90eng/chap.1.htm

Panyarachun, A., chair (2004), 'A More Secure World: Our Shared Reponsibility', Report of the High-level Panel on Threats, Challenges and Change, United Nations General Assembly A/59/565. Retrieved 11 December 2006 from http://www.un.org/secureworld/

Patomäki, H. and T. Teivainen (2004), A Possible World: Democratic Transformation of Global Institutions, London: Zed Books.

Peacock, A.T. and J. Wiseman (1961), The Growth of Public Expenditure in the United Kingdom, Princeton, NJ: Princeton University Press.

Pierson, P. (2000), 'Increasing returns, path dependence and the study of politics', American Political Science Review 94(2): 251-268.

Pocock, J.G.A. (1957), The Ancient Constitution and the Feudal Law, New York: Norton.

Przeworski, A. (2009), 'Conquered or granted? A history of suffrage extensions', British Journal of Political Science 39: 291-321. 
Rabkin, J.A. (2005), Law Without Nations? Why Constitutional Government Requires Sovereign States, Princeton, NJ: Princeton University Press.

Rae, D.W. (1969), 'Decision-rules and individual values in constitutional choice', American Political Science Review 63: 40-56.

Reus-Smit, C. (2003), 'Politics and international legal obligation', European Journal of International Relations 9(4): 591-625.

Risse, T., S.C. Ropp and K. Sikkink (eds) (1999), The Power of Human Rights: International Norms and Domestic Change, Cambridge: Cambridge University Press.

Rokkan, S. (1999), 'State Formation, Nation-building and Mass Politics in Europe', P. Flora with S. Kuhnle and D. Urwin (eds), Oxford: Oxford University Press.

Rose, R. (1976), 'On the priorities of government: a developmental analysis of public policies', European Journal of Political Research 4: 247-289.

Ruggie, J.G. (2007), 'Business and Human Rights: Mapping International Standards of Responsibility and Accountability for Corporate Acts', Report of the Special Representative of the UN Secretary-General on Business and Human Rights, UN Document A/HRC/4/035. Retrieved 19 February 2007 from http://www.business-humanrights.org/ Documents/RuggieHRC2007

Scheuerman, W.E. (2006), 'Critical theory beyond Habermas', in J.S. Dryzek, B. Honig and A. Phillips (eds), Oxford Handbook of Political Theory, Oxford: Oxford University Press, pp. 85-105.

Scott, C. (2002), 'Private regulation of the public sector: a neglected facet of contemporary governance', Journal of Law \& Society 29(1): 56-76.

Segall, J.J. (1982), 'Appeal to the United Nations General Assembly to Consider the Proposal for a UN Second Assembly', presented to Second UN Special Session on Disarmament. (1991), 'A UN Second Assembly', in F. Barnaby (ed.), Building a More Democratic United Nations, London: Frank Cass, pp. 93-109.

Shapiro, I. (1996), 'Elements of democratic justice', Political Theory 24: 579-619.

— (1999), Democratic Justice, New Haven, CT: Yale University Press.

Shklar, J.N. (1991), American Citizenship: The Quest for Inclusion, Cambridge, MA: Harvard University Press.

Somers, M.R. (1994), 'Rights, relationality, and membership: rethinking the making and meaning of citizenship', Law \& Social Inquiry 19(1): 63-112.

Sonenscher, M. (2008), Sans-Culottes: An Eighteenth Century Emblem in the French Revolution, Princeton, NJ: Princeton University Press.

Sørensen, E. and J. Torfing (eds) (2007), Theories of Democratic Network Governance, London: Palgrave Macmillan.

Stinchcombe, A.L. (1968), Constructing Social Theories, New York: Harcourt, Brace \& World. (1974), 'Merton's theory of social structure', in L.A. Coser (ed.), The Idea of Social Structure, New York: Harcourt, Brace \& World.

Strang, D. (1991), 'Global patterns of decolonization, 1500-1987', International Studies Quarterly 35: 429-454.

Suganami, H. (1989), The Domestic Analogy and World Order Proposals, Cambridge: Cambridge University Press.

Tännsjö, T. (1992), Populist Democracy: A Defence, London: Routledge.

- (2008), Global Democracy: The Case for a World Government, Edinburgh: Edinburgh University Press.

Therborn, G. (1977), 'The rule of capital and the rise of democracy', New Left Review 103: $3-41$.

Tilly, C. (1990), Coercion, Capital, and European States, A.D. 990-1990, Oxford: Blackwell. 
- (1997), 'Parlimentarization of popular contention in Great Britain, 1758-1834', Theory and Society 26: 245-273.

- (2001), 'Mechanisms in political processes', Annual Review of Political Science 4: 21-41.

- (2007), Democracy, Cambridge: Cambridge University Press.

Tilly, C. and R.E. Goodin (2006), 'It depends', in R.E. Goodin and C. Tilly (eds), Oxford Handbook of Contextual Political Analysis, Oxford: Oxford University Press, pp. 3-32.

Truman, H.S. (1945), 'Address in San Francisco at the closing session of the United Nations Conference, 26 June 1945’. Retrieved 11 December 2006 from http://www.presidency. ucsb.edu/ws/index.php?pid $=12188$

Tversky, A. and D. Kahneman (1991), 'Loss aversion in riskless choice: a reference-dependent model', Quarterly Journal of Economics 106: 1039-1061.

United Nations Development Program (UNDP) (1999), Globalization with a Human Face: Human Development Report, 1999, New York: Oxford University Press for UNDP.

United Nations, Economic and Social Council (1996), 'Consultative Relationship Between the United Nations and Non-Governmental Organizations', Resolution 1996/31 adopted at 49th plenary meeting. Retrieved 25 July 1996 from http://www.un.org/documents/ ecosoc/res/1996/eres1996-31.html

Valelly, R.M. (2004), The Two Reconstructions: The Struggle for Black Enfranchisement, Chicago: University of Chicago Press.

Warren, C. (1926), The Supreme Court in United States History, rev. edn., Boston: Little, Brown.

Weber, M. (1919), 'Politics as a vocation', in D. Owen and T. B. Strong (eds), The Vocation Lectures, trans. R. Livingstone, Indianapolis, IN: Hackett, 2004, pp. 32-94.

Wendt, A. (2003), 'Why a world state is inevitable', European Journal of International Relations 9(4): 491-542.

Western, B. (2006), Punishment and Inequality in America, New York: Russell Sage Foundation.

Whitehead, L. (2002), Democratization: Theory and Experience, Oxford: Oxford University Press.

Young, I.M. (2000), Inclusion and Democracy, Oxford: Oxford University Press.

Zürn, M. (1998), 'Rise of international environmental politics', World Politics 50(4): 617-649. 